ANDRZEJ LECH

Uniwersytet Łódzki

Wydział Filozoficzno-Historyczny

Instytut Etnologii i Antropologii Kulturowej

\title{
Profesor Maria WieruszeWSKa-AdAMcZYK W UNIWERSYTECIE ŁÓDZKIM
}

$\tau$ ubilatka nie ukrywa, iż Jej macierzystym miastem jest Łódź, macierzystą uczelnią Uniwersytet Łódzki (UŁ), zaś macierzystą jednostką naukową Katedra Etnografii tej uczelni. Z nostalgią wspomina swoje dzieciństwo i młodość, spędzone w naszym mieście, a także studia i pierwsze doświadczenia oraz osiągnięcia badawcze, które kojarzy ze „swoimi” miastem oraz uczelnią.

Przypomnijmy kilka kartek z bogatego życiorysu Marii Wieruszewskiej. Maria - Jolanta urodziła się 15 lutego 1943 r. w Łodzi z ojca Wacława Wieruszewskiego, bankowca po studiach w Uniwersytecie Poznańskim i matki Bronisławy, z domu Kondrackiej.

W 1949 r. Mariolka zaczęła uczyć się w szkole podstawowej i jednocześnie pobierać naukę gry na fortepianie w miejscowym Społecznym Ognisku Muzycznym. Po ukończeniu „podstawówki”, w 1956 r. została uczennicą VII LO im. Stefanii Sempołowskiej i jednocześnie podjęła naukę w Państwowej Średniej Szkole Muzycznej w Łodzi. Po chlubnie uzyskanej maturze w 1960 r. swój talent jednoznacznie poświęciła studiom humanistycznym, podejmując naukę na etnografii w UŁ.

Podczas studiów zaczęła się odnajdywać nie tylko jako studentka, bardzo dobrze zaliczająca kolejne przedmioty kierunkowe i egzaminy, ale również jako animatorka pozaprogramowego studenckiego ruchu naukowego. W latach 1964-1965 była przewodniczącą, wyjątkowo wówczas aktywnego, Studenckiego Koła Etnografów. 
Studiując, uczęszczała na wykłady wybitnych polskich humanistów, m.in. prof. prof. Antoniny Kłoskowskiej, Jana Lutyńskiego, Wacława Piotrowskiego i Jana Szczepańskiego. Wiedza, uzyskiwana od tych uczonych, wpłynęła na ostateczne wykrystalizowanie się zainteresowań badawczych i metodologii naukowej przyszłej teoretyczki, stawiającej przed sobą, już wówczas, ambitne zamierzenia, które jak sama napisała:

Kształtowały się (...) w klimacie ścisłych związków etnografii z badaniami społecznymi. Umacniał to program studiów, ale było to także zasługą prof. Kazimiery Zawistowicz-Adamskiej, pierwszego i długoletniego kierownika Katedry Etnografii (...) - twórczyni łódzkiej szkoły etnograficznej. Okres moich studiów to czas wchodzenia w środowisko naukowe zajmujące się badaniami wsi polskiej, dzięki współpracy Katedry z pracownikami muzeów etnograficznych oraz badaniami zgrupowanymi w Polskim Towarzystwie Ludoznawczym (.... ${ }^{1}$.

Tak więc, będąc jeszcze studentką, Maria Wieruszewska uznała prof. K. Zawistowicz-Adamską za swoją mistrzynię².

Pod wpływem Pani Profesor, biorąc udział w badaniach na terenie nowopowstającego Bełchatowskiego Okręgu Przemysłowego, młoda badaczka skupiła swoje zainteresowania wokół problematyki norm współżycia w społeczności wiejskiej, tracącej, pod wpływem uprzemysłowienia, tradycyjny charakter. Podjęła pionierskie badania terenowe, dotyczące problemów słabo dotychczas rozpoznanych w polskiej etnografii i jednocześnie wprowadzających tę naukę w obręb zainteresowań interdyscyplinarnych. Zaowocowały one pracą magisterską: Obrzędy recepcyjne wieku dojrzałego w Bełchatowskiem, opracowaną pod kierunkiem prof. K. Zawistowicz-Adamskiej. Praca ta pozwoliła zwieńczyć studia bardzo dobrze zdanym egzaminem (30 VI 1965 r.) i tytułem magistra ${ }^{3}$. W tej sytuacji naturalnym stało się uzyskanie przez mgr M. Wieruszewską stażu i asystentury w Katedrze Etnografii UŁ, od roku akademickiego 1965/1966 i jednocześnie

${ }^{1}$ Dział Spraw Pracowniczych UŁ (DSP UŁ), Teczka osobowa. Wieruszewska-Adamczyk Maria, sygn. 1635, Maria Wieruszewska, Autoreferat informujący o zainteresowaniach i osiągnięciach w działalności naukowo-badawczej oraz kształtowaniu kadr naukowych, s. 1 (maszynopis).

2 Pisała: „Uważam się za uczennicę Kazimiery Zawistowicz-Adamskiej”, Archiwum Prywatne prof. Marii Wieruszewskiej - APMW, Prof. dr hab. Maria Wieruszewska, Autoreferat informujący o zainteresowaniach i osiągnięciach w działalności naukowo-badawczej oraz w kształtowaniu kadr naukowych, Warszawa luty 2001, s. 2.

${ }^{3}$ M. Wieruszewska, Obrzędy recepcyjne wieku dojrzałego w Bełchatowskiem, „Łódzkie Studia Etnograficzne", T. VIII, R. 1966, s. 23-82. 
umożliwiło kontynuowanie pracy naukowej, która, jak napisała wówczas „(...) stanowi cel i marzenie mojego życia”4.

Od pierwszego roku zatrudnienia w UŁ przejęła prowadzenie zajęć dla studentów etnografii w formie ćwiczeń z „etnografii Polski” oraz wiosennych i letnich ćwiczeń terenowych. Zaczęła przekazywać im swoją wiedzę, ale również niezwykłe umiejętności związane ze zdobywaniem źródeł wywołanych. Prof. K. Zawistowicz-Adamska walory te określiła następująco: „M. Wieruszewska umie współżyć ze społecznością wiejską, co ułatwia Jej uzyskiwanie wszechstronnych i cennych informacji”5. Początkująca asystentka istotnie wzbogacała też swoje zdolności dydaktyczne jako uczestniczka, w roku akad. 1965/1966, asystenckich studiów przygotowawczych w UŁ.

Wkrótce po ukończeniu studiów Maria Wieruszewska zmieniła stan cywilny. W 1967 r. wyszła za mąż za Stanisława Adamczyka i zamieszkała w Warszawie, zaś w następnym roku urodziła Rafała, jedynego, najukochańszego syna. Napisała po latach:

Praca asystenta w Katedrze Etnografii UŁ, później adiunkta, wymagała ode mnie niełatwego godzenia ról matki i żony z obowiązkami zawodowymi (badawczymi i dydaktycznymi) ${ }^{6}$.

Jeszcze jako magister, w końcu lat 60. XX w., podjęła współpracę ze środowiskiem warszawskim. Początkowo w ramach 9. miesięcznego stażu (od 1 X 1968 r.) w Instytucie Socjologii i Filozofii PAN (dyrektor prof. Jan Szczepański), pod opieką dr. Franciszka Jakubczyka, zgłębiała zagadnienia dotyczące socjologii wsi. Następnie, w związku z reorganizacją tej placówki, współdziałała z Zakładem Badań Rejonów Uprzemysłowionych PAN (ZBRU) do którego została skierowana na dłuższy, półtoraroczny staż od 10 VI 1969 r. (do 31 III 1970 r.) ${ }^{7}$. Uczestniczyła w seminariach i konferencjach organizowanych przez Zakład. Publikowała drobniejsze artykuły popularno-naukowe, klasycznie etnograficzne, w takich pismach jak „Teatr

\footnotetext{
${ }^{4}$ DSP UŁ, Teczka osobowa (...) Maria Wieruszewska, Życiorys, 30 XI 1965 r., s. 1 (rękopis).

${ }_{5}$ APMW, Prof. dr Kazimiera Zawistowicz-Adamska, Opinia o pracy naukowej dr Marii Wieruszewskiej-Adamczykowej, Łódź 10 X 72, s. 1. (rękopis).

${ }^{6}$ APMW, Prof. dr hab. Maria Wieruszewska, Życiorys, Warszawa czerwiec 1998 r., s. 2. (maszynopis).

7 DSP UŁ, Teczka osobowa... Pismo Rektora UŁ prof. dr Z. Skwarczyńskiego z dn. 5 XI 1969 r. do Zakładu Badań Regionów Uprzemysłowionych Polskiej Akademii Nauk.
} 
Ludowy”, „Tygodnik Kulturalny”, „Zielony Sztandar”, „Problemy Rodziny” oraz pierwsze analizy badawcze w "tódzkich Studiach Etnograficznych”. Prowadziła samodzielne badania finansowane przez ZBRU (przekształcony w 1971 r. w Instytut Rozwoju Wsi i Rolnictwa PAN - IRWiR PAN) w powiecie bełchatowskim, zmieniającym swój charakter ekonomiczno-społeczny $\mathrm{z}$ rolniczego na przesyłowo-rolniczy.

Badania w Bełchatowskiem zmierzały do opracowania, oryginalnej wówczas, problematyki sankcji systemu kontroli społecznej wobec życia rodziny wiejskiej. Ostatecznie przybrały postać pracy doktorskiej: Sankcje systemu kontroli społecznej wobec życia rodziny wiejskiej, na przykładzie badań dwóch wsi powiatu bełchatowskiego, napisaną pod kierunkiem prof. K. Zawistowicz-Adamskiej, wzorowo obronionej na Wydziale Filozoficzno-Historycznym UŁ w 1970 r. (Uchwała Rady Wydziału z 17 XII 1970 r.) ${ }^{8}$. Recenzenci dysertacji nie szczędzili Autorce pochwał, doceniając Jej dzieło na tle najnowszych osiągnięć polskiej humanistyki. Prof. A. Kłoskowska napisała:

(...) zaletą pracy jest zastosowanie ogólnych koncepcji socjologicznych, wykorzystywanych dotąd w monograficznych pracach prawie wyłącznie na gruncie społeczeństw pierwotnych, do współczesnego materiału polskiego ze znamiennymi dla niego cechami właściwymi stosunkom szybko rozwijającego się społeczeństwa podlegającego procesom socjalistycznej industrializacji ${ }^{9}$.

Doskonaląc metodę etnograficzną pozyskiwania źródeł, początkowo jako magister, Maria Wieruszewska, w ramach badań własnych, od lipca $1970 \mathrm{r}$. do sierpnia roku następnego prowadziła badania terenowe we wsi Kłotno na Kujawach (pow. włocławski). Prace te podejmowane były przez Katedrę Etnografii UŁ, jako badania zespołowe (kierownik doc. Bronisława Kopczyńska -Jaworska) na zlecenie ówczesnego Komitetu Badania Rejonów Uprzemysłowionych PAN. Stanowiły istotny fragment działań prowadzonych przez zespoły socjologów, ekonomistów i prawników. Etnografowie odnaleźli swoje miejsce wśród całości tych badań o charakterze interdyscyplinarnym,

\footnotetext{
${ }^{8}$ Praca ta została opublikowana. M. Wieruszewska, Sankcje systemu kontroli społecznej wobec rodziny wiejskiej, „Łódzkie Studia Etnograficzne”, t. XIII, R. 1971.

9 APMW, Prof. dr Antonia Kłoskowska, Recenzja pracy doktorskiej mgr Marii Wieruszewskiej „Sankcje systemu kontroli społecznej wobec rodziny wiejskiej na przykładzie dwóch wybranych wsi powiatu bełchatowskiego", s. 2. (maszynopis b.d.)
} 
określając stosunek mieszkańców wsi do ziemi ${ }^{10}$. Solidna analiza, która powstała na bazie materiałów zebranych w Kłotnie, wpisała Marię Wieruszewską do grona czołowych badaczy problematyki wiejskiej ${ }^{11}$.

Formalnie nowy rozdział życia naukowego rozpoczęła dr Maria Wieruszewska-Adamczyk od 1 XII 1971 r. Uzyskała wówczas

(...) służbowe przeniesienie za zgodą wszystkich zainteresowanych stron t.j. kierownika Katedry Etnografii doc. Jaworskiej, dyrektora mojego aktualnego instytutu prof. Gałaja $(. . .)^{12}$.

O przejściu do Warszawy zadecydowały względy rodzinne, uciążliwości związane z dojazdem ze stolicy do Łodzi, ale również decydująco powiązania naukowe z IRWiR PAN. W podaniu o przeniesienie napisała:

IRWiR - jest placówką o ugruntowanych kontaktach ze środowiskiem łódzkich etnografów, czego wyrazem są prowadzone od lat badania, w których uczestniczyłam jako pracownik Katedry Etnografii (...) Mam więc nadzieję, że moje przejście do IRWiR wzmocni kontakty naukowe macierzystej Katedry i UŁ z nowopowstałą placówką ${ }^{13}$.

Tak też się stało, z wielkim pożytkiem dla badań i poziomu naukowego obu środowisk.

Inspiracje oraz dorobek naukowy z czasów pracy w UŁ, zaowocowały podjęciem przez młodą uczoną nowej tematyki badawczej. Odnalazła ona, z pożytkiem dla swojej dojrzałości naukowej

(...) możliwość śledzenia wewnętrznych zmian kilku dyscyplin naukowych zajmujących się problemami wsi, a więc ekonomiki rolnej, etnografii, demografii, geografii, socjologii. Daje to szansę dostrzeżenia płaszczyzn wspólnych między nimi. Pozwala zauważyć zmiany we wzorach badań. Przełamanie dotychczasowych jednostronnych interpretacji, czemu służy analiza krytyczna, pomaga w zdobywaniu przez niektóre dyscypliny tego, co można by nazwać samoświadomością, czy też wiedzą na temat swego rodowodu intelektualnego ${ }^{14}$.

${ }_{10}$ Por. B. Kopczyńska-Jaworska, Założenia, problematyka i organizacja badań, [w:] Stosunek mieszkańców wsi Kujawskiej do ziemi. Przemiany kulturowej hierarchii wartości, pod red. B. Kopczyńskiej-Jaworskiej, Łódź 1974, s. 7-17.

${ }^{11}$ Wielowymiarowość wartości ziemi i jej społeczno-kulturowe determinanty we wsi Kłotno, [w:] Tamże, s. 150-182.

12 DSP UŁ, Teczka osobowa... Maria Wieruszewska, Życiorys... s. 2.

${ }_{13}$ DSP UŁ, Teczka osobowa... Dr Maria Wieruszewska-Adamczyk: Podanie o przeniesienie do IRWiR PAN z 26 XI 1971 r., s. 1 (maszynopis).

${ }^{14}$ APMW, Prof. dr hab. Maria Wieruszewska, Życiorys... s. 3. 
Korzystając z rad prof. K. Zawistowicz-Adamskiej, dr Maria Wieruszewska zajęła się, tak jak Jej Mistrzyni, Zaborowem, wsią leżącą w widłach Dunajca i Uszwicy ${ }^{15}$. Pisała na ten temat:

Posługując się tym samym kwestionariuszem, który wykorzystano przy indagowaniu wszystkich głów rodzin Zaborowskich w badaniach przed 35 lat, udało mi się zachować porównywalność wielu cech życia wsi w dwóch okresach czasu. Samodzielne wywiady z mieszkańcami wsi wzbogaciły materiał i okazały się dobrym źródłem informacji docierającym do imponderabiliów życia społecznego, niełatwo dającym się odnotować w ankiecie ${ }^{16}$.

Rezultaty badań zaborowskich zawarte zostały w rozprawie habilitacyjnej (przewód na Wydziale Filozoficzno-Historycznym UŁ 22 XI 1979 r.) i w książce: Przemiany społeczności wiejskiej. Zaborów po 35 latach (Wyd. IRWiR PAN, Warszawa 1978). Oceniając działo habilitantki, wybitna uczona z ówczesnej Katedry Etnografii UW, prof. Anna Kutrzeba-Pojnarowa stwierdziła:

Praca jest poważnym wkładem w teorię funkcjonowania i zmian społeczności wiejskiej. Przynosi również bogaty materiał ujęty w dużej mierze (choć nie wyłącznie) statystycznie, nadający się do studiów porównawczych, które powinny być podjęte w myśl propozycji tutaj wysuniętej. Nie przeszkadza to wysunięciu następnego postulatu udostępnienia dalszych materiałów opisowych (...) w formie przeznaczonej dla (...) samych emigrantów z Zaborowa, którzy - w Chicago - wykazali tyle wciąż trwałych związków z terenem i społecznością swego pochodzenia ${ }^{17}$.

Dorobek naukowy, opracowany na bazie badań Zaborowskich, został w różny sposób też doceniony przynajmniej dwukrotnie. Najpierw Autorka uzyskała prestiżową nagrodę Sekretarza Naukowego PAN w 1980 r. za książkę Przemiany społeczności wiejskiej. Następnie w roku akademickim 1975-1976, z rekomendacji Dyrektora IRWiR PAN, otrzymała stypendium Fundacji Kościuszkowskiej na Uniwersytecie Chicagowskim ${ }^{18}$.

${ }^{15}$ K. Zawistowicz-Adamska, Społeczność wiejska. Doświadczenia i rozważania z badań terenowych w Zaborowie, Polski Instytut Służby Społecznej, Łódź 1948, ss. 227.

${ }^{16}$ APMW, Prof. dr hab. Maria Wieruszewska, Autoreferat..., s. 2.

17 APMW, Prof. dr Anna Kutrzeba-Pojnarowa, Ocena pracy dr Marii Wieruszewskiej p.t. Przemiany społeczności wiejskiej (powtórka monografii Zaborowa), Warszawa 5.8.1977, s. 2-3 (maszynopis).

18 Prof. dr Dyzma Gałaj wyraził opinię, że „Wyniki zaprojektowanych badań dr Wieruszewskiej - Adamczyk w Stanach Zjednoczonych, w konfrontacji z osiągnięciami badań prowadzonych aktualnie w kraju, miałyby niezwykle cenne walory metodologiczne wyjaśniające wiele interesujących zagadnień w społeczności amerykańskiej". APMW, Pismo do ob. Wiesława 
Po latach pisała:

Z badaniami zaborowskimi należy łączyć mój wyjazd do Stanów Zjednoczonych w roku 1976 na 10-miesięczne stypendium Fundacji Kościuszkowskiej. Podążając śladem rodzin zaborowskich, które wyemigrowały z Polski do USA i które tworzyły jeden z silniejszych klubów Małopolskich dotarłam do Chicago. Mój program pobytu obejmował zajęcia na Uniwersytecie Chicagowskim z zakresu psychologii społecznej i socjologii oraz antropologii kulturowej. Równocześnie prowadziłam badania wśród grupy Polonii wywodzącej się z Zaborowa ${ }^{19}$.

Tymczasem związki doc. Marii Wieruszewskiej z Łodzią były nadal intensywne, także ze względów rodzinnych. Po powrocie do kraju, w drugiej połowie 1976 r. i później po śmierci męża, sama zajęła się wychowaniem syna i „odbudowaniem gospodarstwa domowego”. Jeszcze wówczas mogła liczyć na pomoc mieszkających w Łodzi rodziców. Gdy 17 stycznia 1988 r. zmarł

(...) ukochany ojciec - jak pisze - i na mnie, lecz głównie na moim młodszym, mieszkającym w Łodzi, bracie Januszu, spoczywa troska o matkę. Niełatwa opieka nad trójką małych dzieci, w tym jednym z porażeniem mózgowym, poszerza i z czasem zwiększa zakres moich obowiązków rodzinnych ${ }^{20}$.

Tak więc wizyty w Łodzi nie tylko nie ustawały, a nawet stały się częstsze. Swoisty transfer do IRWiR PAN okazał się nader pożytecznym dla rozwoju naukowego dr Marii Wieruszewskiej, jak i dla podniesienia poziomu merytorycznego i szerszego oraz bardziej różnorodnego tematycznie zakresu badań tej placówki. W niej młoda uczona, korzystając z życzliwej opieki i doświadczeń pierwszego dyrektora IRWiR PAN, prof. Dyzmy Gałaja, wyrosła na czołowego animatora naukowo-badawczego Instytutu. Pełniąc funkcję zastępcy dyrektora d/s naukowych w IRWiR PAN (lata 1986-1991) jednocześnie została sekretarzem Centralnego Problemu Badań Podstawowych, który instytut ten koordynował w latach 1986-1990.

W roku 1991, jeszcze jako docent, Maria Wieruszewska została pierwszym demokratycznie wybranym dyrektorem IRWiR PAN. Pełniła tę funkcję nieprzerwanie przez dwie kadencje do marca 1997 r.:

Adamskiego, Podsekretarza Stanu MSZ, Sekretarza Generalnego Towarzystwa Łączności z Polonią Zagraniczną „Polonia”, Warszawa 9 XI 1974 r., s. 1 (maszynopis).

${ }^{19}$ APMW, Prof. dr hab. Maria Wieruszewska, Autoreferat..., s. 2.

${ }^{20}$ APMW, Prof. dr hab. Maria Wieruszewska, Życiorys..., s. 2. 
Objęcie funkcji dyrektora Instytutu Rozwoju Wsi i Rolnictwa PAN w marcu 1991 roku było dla mnie równoznaczne z wzięciem na siebie odpowiedzialności za taki kierunek badań, który służyłby integralnemu rozwojowi wsi w jej wielu wymiarach. Przykładem tego jest powołanie do istnienia w ramach IRWiR Zakładu Kultury Wsi, także zmiana profilu kwartalnika „Wieś i Rolnictwo”, który już w nowej szacie ukazał się w 1992 roku. Do roku 1996 pełniłam funkcję redaktora naczelnego kwartalnika, co sprzyjało zacieśnieniu mojej współpracy ze środowiskami naukowymi wielu różnych specjalności zajmujących się badaniami wsi i rolnictwa ${ }^{21}$.

Ze względu na swoją wiedzę i doświadczenia Uczona została powołana na Członka Rady Prezydenckiej do Spraw Wsi i Rolnictwa ${ }^{22}$. Udzielała się także aktywnie w Radzie Programowej „Agrolinia 2000” oraz w Rolniczym Forum Europy Środkowej i Wschodniej. Po zakończeniu drugiej kadencji na stanowisku dyrektorskim, pracuje w dalszym ciągu intensywnie w Zakładzie Socjologii i Antropologii Kultury Wsi (kierownik: prof. Izabella Bukraba-Rylska), który powstał z przekształcenia wymienionego wyżej Zakładu Kultury Wsi.

Kolejny etap życia naukowego Jubilatki łączył się z Jej swoistym powrotem do Łodzi. Gdy 1 X 1998 roku objęła stanowisko profesora nadzwyczajnego w Katedrze Etnologii UŁ, jako drugim miejscu pracy, z pensum dydaktycznym 210 godzin, była już cenionym autorytetem w środowisku badaczy problematyki wiejskiej, z tytułem naukowym profesora nauk humanistycznych, który uzyskała 12 V 1992 r. od Prezydenta Rzeczypospolitej Lecha Wałęsy. Jej podanie do J. M. Rektora UŁ w sprawie przyjęcia do pracy rekomendował następująco Dziekan Wydziału Filozoficzno-Historycznego (prof. dr hab. Jan Szymczak): „Popieram bardzo gorąco, albowiem stanowi to kolejny krok do wzmocnienia kadry w Katedrze Etnologii"23.

Od początku roku akad. 1998/1999 rozpoczęły się więc długoletnie, naukowo-dydaktyczne, sformalizowane kontakty z macierzystym ośrodkiem naukowym, najpierw w ramach Katedry Etnologii, później Instytutu

${ }^{21}$ APMW, Prof. dr hab. Maria Wieruszewska, Autoreferat..., s. 3.

22 APMW, Pismo Sekretarza Stanu w Kancelarii Prezydenta Rzeczypospolitej Polskiej Andrzeja Zakrzewskiego do Prof. dr hab. Marii Wieruszewskiej-Adamczyk, „Wielce Szanowna Pani, Proszę przyjąć serdeczne wyrazy podziękowania za bardzo interesujące refleksje i uwagi na temat szans i zagrożeń związanych z dokonującymi się w Polsce przemianami ustrojowymi. Ich przebieg i charakter to nadal sprawa otwarta. Pani wypowiedź pozwala jednakże zrozumieć, co stało się w Polsce w ostatnich latach i co może się wydarzyć w najbliższej przyszłości. Ma więc dla mnie szczególną wartość. Cenię ją sobie również dlatego, że skłania - jak każda trafna diagnoza - do zastanowienia się nad sposobami przezwyciężenia trudności, które trapią nasz kraj." (Warszawa, 1994.04.29).

${ }^{23}$ DSP UŁ, Opinia Dziekana Wydziału Filozoficzno-Historycznego Prof. dr hab. Jana Szymczaka, 30 IV $1998 \mathrm{r}$. 
Etnologii i Antropologii Kulturowej i wewnątrz Instytutu w składzie kadrowym Zakładu Etnologii Polski i Europy, a od 1 X 2011, po przekształceniu tej jednostki, aż do przejścia na emeryturę 30 IX 2013 r., w Zakładzie Etnologii i Folklorystyki. W sposób znaczący Jubilatka przyczyniła się do wzbogacenia dorobku naukowego i poziomu badań łódzkiego środowiska etnologicznego. Nadawała ton zebraniom naukowym swojego zakładu naukowego. Oceniała koncepcje prac doktorskich, opiekowała się nimi, inspirowała studentów i młodych naukowców do podejmowania nowych wyzwań badawczych. Można bez przesady stwierdzić, że okazała się najwybitniejszym naukowcem w składzie Zakładu Etnologii Polski i Europy.

Prof. Maria Wieruszewska, wracając do UŁ, uzyskała też możliwość doskonalenia swoich umiejętności dydaktycznych. Rozpoczęła zajęcia w formie wykładów, przeważnie dla V r. etnologii (studia dzienne i wieczorowe): „Badanie świata współczesnego - wieś i miasto”, „Antropologia współczesności”. Problematyka tych i innych wykładów dotyczyła głównie społeczno-kulturowych problemów wsi i obszarów wiejskich w Europie i Polsce. Od roku akad. 2007/2008 objęła też seminarium magisterskie z problematyki szeroko pojętej antropologii kulturowej dla IV i V r. etnologii. Jej zajęcia dydaktyczne, oparte na głębokiej wiedzy z zakresu etnologii, socjologii i w ogóle antropologii kulturowej, nawiązujące do własnych badań, cieszyły się uznaniem i najwyższymi ocenami studentów. Zaowocowały nie tylko pracami seminaryjnymi, magisterskimi, ale nawet doktorskimi.

W sferze badań naukowych, podczas pracy w UŁ, Jubilatka mocno włączyła się w nurt dotyczący miejsca i roli wsi oraz rolnictwa w procesie integracji Polski z Unią Europejską. W licznych publikacjach, referatach na konferencjach krajowych i międzynarodowych, jawi się jako zwolenniczka przekonania, iż „(...) to nie miejskość a wiejskość będzie określała przyszły kształt Europy"24.

Nadając ton pracom badawczym Zakładu Etnologii Polski i Europy projektowała i przeprowadzała m.in. tzw. badania własne w roku 2008 (umowa 505/323). Dotyczyły one jakże ważnego, oryginalnego i aktualnego, jeszcze niewystarczająco rozpoznanego, zagadnienia: Tożsamość kulturowa wsi $w$ świecie ponowoczesnym. Wyniki tych prac, zawarte w szeregu pracach

${ }^{24}$ M. Wieruszewska, Wieś jako wyzwanie dla procesu integracji Europejskiej - mit czy nadzieja?, [w:] Wieś i rolnictwo w procesie integracji Polski z Uniq̨ Europejskq, red. E. Kośmicki, H. Januszek, W. L. Janik, Poznań 1998, s. 21. 
publikowanych w kraju, jak również w referatach na konferencjach międzynarodowych, sugerowały nową konceptualizację wiejskości, którą powinna odejść od takich dychotomii jak: wieś - miasto, tradycja - nowoczesność, wspólnota - stowarzyszenie, partykularyzm - uniwersalizm.

Prof. Maria Wieruszewska zaznaczyła też wyraziście swoją aktywność naukową w pracach Interdyscyplinarnego Zespołu Badania Wsi UŁ, funkcjonującego przy Instytucie Etnologii i Antropologii Kulturowej. Występowała z referatami na zebraniach Zespołu, publikowała w jego biuletynie naukowym, a także recenzowała do druku niektóre tomy „Zeszytów Wiejskich”25, przedstawiała referaty na sesjach plenarnych, konferencjach naukowych organizowanych przez Zespół.

Podobnie, Muzeum Etnograficzne i Archeologiczne w Łodzi mogło korzystać, z pożytkiem dla siebie, z dorobku i autorytetu naukowego Jubilatki, która w 1998 r. opracowała merytorycznie katalog wystawy Szare jak ziemia barwne jak pamięć, dotyczącej kultury ludowej Łódzkiego i pełniła funkcję Przewodniczącej Rady Muzealnej tej placówki.

Podczas aktywności w środowisku łódzkim, ale też w uznaniu wysokiej pozycji w ogóle w polskiej etnologii, Uczona wybierana była do Komitetu Nauk Etnologicznych. Reprezentowała również łódzką etnologię w Uniwersyteckiej Komisji Akredytacyjnej dla kierunku etnologia. M. in. 21-23 maja 2001 r. brała udział w zespole oceniającym ten kierunek studiów na Wydziale Historycznym Uniwersytetu Jagiellońskiego.

0 wyjątkowym prestiżu prof. M. Wieruszewskiej w łódzkim środowisku nauk społecznych i humanistycznych zaświadcza wybranie Jej, jako promotora, do odnowienia po 50. latach doktoratu współtwórczyni i wieloletniej kierownik Katedry Etnografii/Etnologii UŁ, prof. dr hab. Bronisławy Kopczyńskiej-Jaworskiej. Uroczystość odbyła się 25 V 2009 r., na posiedzeniu Senatu UŁ. W pełnym swady i serdeczności wystąpieniu, jako młodsza koleżanka, wzrastająca naukowo pod wpływem obchodzącej jubileusz Uczonej, stwierdziła:

Trudno odszukać ten zakres aktywności łódzkiego środowiska etnologicznego, w którym nie byłoby widać wiodącej roli Pani Profesor. Polscy etnografowie różnych

${ }^{25}$ Np. M. Wieruszewska, Mentalność jako kategoria opisu rzeczywistości wiejskiej, „Zeszyty Wiejskie”, Z. X, 2005, s. 9-19; Tejże, Programy szkolenia liderów wiejskich. Potrzeby a rzeczywistość, „Zeszyty Wiejskie”, Z. II, 2000, s. 23-34. 
pokoleń są Jej dłużnikami z racji - nieprzerwanej od półwiecza - niespożytej aktywności organizacyjnej, dydaktycznej i naukowej, którą realizowała reprezentując polską etnografię w krajowych i międzynarodowych organizacjach ${ }^{26}$.

Działając w Łodzi miała okazję na wzbogacenie zasięgu swoich kontaktów międzynarodowych, które wysoko ustalały Jej pozycję nie tylko w nauce polskiej, ale także w ogóle europejskiej. Pozostawała przy tym wierna wybranej przez siebie problematyce: „Moja współpraca zagraniczna wiąże się z badaniami naukowymi, dotyczącymi głównie społeczno-kulturalnych problemów wsi i obszarów wiejskich w Polsce"27. Szczególną estymą obdarzała etnologów skandynawskich, podejmując z nimi współpracę w ramach programu badań Morza Bałtyckiego (Baltic Sea Region Studies). W zakresie kontaktów z Uniwersytetem w Turku (Finlandia) przyjęła, w IEiAK, prof. Pekka Leimu z Instytutu Etnologii tej uczelni.

W uznaniu zasług dla rozwoju łódzkiego ośrodka etnologicznego, z inicjatywy Rady Naukowej IEiAK, prof. M. Wieruszewska 15 VII 2009 r. została odznaczona najwyższym odznaczeniem resortowym (Ministra Nauki i Szkolnictwa Wyższego) czyli Medalem Komisji Edukacji Narodowej. Uzasadniając wniosek Dziekan Wydziału Filozoficzno-Historycznego UŁ (Prof. dr hab. Zbigniew Anusik) stwierdził, iż „Jej olbrzymią zasługą jest ukazanie wsi polskiej jako całości społeczno-kulturowej i rozwijanie koncepcji tożsamości kulturowej wsi jako podstawy zmian kulturowych w Europie XX i XXI w."28. Pani Profesor już wcześniej odznaczona była Złotym Krzyżem Zasługi (29 XI 1995 r.), zaś później Krzyżem Kawalerskim Orderu Odrodzenia Polski (29 IX 2011 r.).

Głównie dwie placówki naukowe i związane z nimi środowiska, nawet szkoły badawcze, wywarły przemożny wpływ na ostateczne ukształtowanie się sylwetki badawczej prof. Marii Wieruszewskiej. Początkowo Katedra Etnografii UŁ, później zaś IRWiR PAN, wykrystalizowały i umocniły interdyscyplinarne podejście Jubilatki do problematyki wiejskiej, czyli metodologię będącą najlepszym przykładem twórczego połączenia perspektywy etnologicznej i socjologicznej oraz wspólnego traktowania problemów kultury

${ }^{26}$ M. Wieruszewska-Adamczyk, Odnowienie doktoratu prof. dr hab. Bronisławy Kopczyńskiej-Jaworskiej w dniu 25 maja 2009 r., „Zeszyty Wiejskie”, Z. XV, 2010, s. 292-294.

27 APMW, Prof. dr hab. Maria Wieruszewska, Autoreferat..., s. 3.

${ }^{28}$ DSP UŁ, Teczka osobowa... Uzasadnienie wniosku o przyznanie Medalu Komisji Edukacji Narodowej (maszynopis). 
(tradycyjnie wiązanych z etnografią) i społeczeństwa (przypisywanych socjologii). Jej dorobek świadczy o tym, że do zrozumienia złożonych problemów współczesnej wsi, przeobrażeń jakim podlega, konieczne jest łączenie różnych perspektyw i punktów widzenia antropologii kulturowej.

\section{BIBLIOGRAFIA}

- Kopczyńska-Jaworska B., Założenia, problematyka i organizacja badań, [w:] Stosunek mieszkańców wsi Kujawskiej do ziemi. Przemiany kulturowej hierarchii wartości, pod red. B. Kopczyńskiej-Jaworskiej, Łódź 1974.

- Wieruszewska M., Mentalność jako kategoria opisu rzeczywistości wiejskiej, „Zeszyty Wiejskie", Z. X, 2005.

- Wieruszewska M., Obrzędy recepcyjne wieku dojrzałego w Bełchatowskiem, „Łódzkie Studia Etnograficzne", T. VIII, R. 1966.

- Wieruszewska M., Programy szkolenia liderów wiejskich. Potrzeby a rzeczywistość, „Zeszyty Wiejskie”, Z. II, 2000.

- Wieruszewska M., Sankcje systemu kontroli społecznej wobec rodziny wiejskiej, „Łódzkie Studia Etnograficzne", t. XIII, R. 1971.

- Wieruszewska M., Wieś jako wyzwanie dla procesu integracji Europejskiej - mit czy nadzieja?, [w:] Wieś i rolnictwo w procesie integracji Polski z Uniq Europejska, red. E. Kośmicki, H. Januszek, W. L. Janik, Poznań 1998.

- Wieruszewska-Adamczyk M., Odnowienie doktoratu prof. dr hab. Bronisławy Kopczyńskiej-Jaworskiej w dniu 25 maja 2009 r., „Zeszy ty Wiejskie”, Z. XV, 2010.

- Wieruszewska-Adamczyk M., Wielowymiarowość wartości ziemi i jej społeczno-kulturowe determinanty we wsi Kłotno, [w:] Stosunek mieszkańców wsi Kujawskiej do ziemi. Przemiany kulturowej hierarchii wartości, pod red. B. Kopczyńskiej-Jaworskiej, Łódź 1974.

- Zawistowicz-Adamska K., Społeczność wiejska. Doświadczenia i rozważania z badań terenowych w Zaborowie, Polski Instytut Służby Społecznej, Łódź 1948.

\section{MATERIAEY ARCHIWALNE}

- Archiwum Prywatne prof. Marii Wieruszewskiej, Pismo do ob. Wiesława Adamskiego, Podsekretarza Stanu MSZ, Sekretarza Generalnego Towarzystwa Łączności z Polonią Zagraniczną „Polonia”, Warszawa 9 XI 1974 r. (maszynopis).

- Archiwum Prywatne prof. Marii Wieruszewskiej, Pismo Sekretarza Stanu w Kancelarii Prezydenta Rzeczypospolitej Polskiej Andrzeja Zakrzewskiego do Prof. dr hab. Marii Wieruszewskiej-Adamczyk (Warszawa, 1994.04.29). 
- Archiwum Prywatne prof. Marii Wieruszewskiej, Prof. dr Anna Kutrzeba-Pojnarowa, Ocena pracy dr Marii Wieruszewskiej p.t. Przemiany społeczności wiejskiej (powtórka monografii Zaborowa), Warszawa 5.8.1977 (maszynopis).

- Archiwum Prywatne prof. Marii Wieruszewskiej, Prof. dr Antonia Kłoskowska, Recenzja pracy doktorskiej mgr Marii Wieruszewskiej „Sankcje systemu kontroli społecznej wobec rodziny wiejskiej na przykładzie dwóch wybranych wsi powiatu bełchatowskiego" (maszynopis b.d.).

- Archiwum Prywatne prof. Marii Wieruszewskiej, Prof. dr Kazimiera Zawistowicz-Adamska, Opinia o pracy naukowej dr Marii Wieruszewskiej-Adamczykowej, Łódź 10 X 72 (rękopis).

- Archiwum Prywatne prof. Marii Wieruszewskiej, Prof. dr hab. Maria Wieruszewska, Autoreferat informujący o zainteresowaniach i osiągnięciach w działalności naukowo-badawczej oraz w kształtowaniu kadr naukowych, Warszawa luty 2001.

- Archiwum Prywatne prof. Marii Wieruszewskiej, Prof. dr hab. Maria Wieruszewska, Życiorys, Warszawa czerwiec 1998 r. (maszynopis).

- Dział Spraw Pracowniczych UŁ, Teczka osobowa. Wieruszewska-Adamczyk Maria, sygn. 1635, Maria Wieruszewska: Autoreferat informujący o zainteresowaniach i osiągnięciach w działalności naukowo-badawczej oraz kształtowaniu kadr naukowych (maszynopis)

- Dział Spraw Pracowniczych UŁ, Teczka osobowa. Wieruszewska-Adamczyk Maria, sygn. 1635, Maria Wieruszewska, Życiorys, 30 XI 1965 r. (rękopis).

- Dział Spraw Pracowniczych UŁ, Teczka osobowa. Wieruszewska-Adamczyk Maria, sygn. 1635, Pismo Rektora UŁ prof. dr Z. Skwarczyńskiego z dn. 5 XI 1969 r. do Zakładu Badań Regionów Uprzemysłowionych Polskiej Akademii Nauk.

- Dział Spraw Pracowniczych UŁ, Teczka osobowa. Wieruszewska-Adamczyk Maria, sygn. 1635, Dr Maria Wieruszewska-Adamczyk, Podanie o przeniesienie do IRWiR PAN z 26 XI 1971 r. (maszynopis).

- Dział Spraw Pracowniczych UŁ, Teczka osobowa. Wieruszewska-Adamczyk Maria, sygn. 1635, Uzasadnienie wniosku o przyznanie Medalu Komisji Edukacji Narodowej (maszynopis).

\section{ProfesSor MARIA WiERUSZEWSKA-AdAMCZYK AT THE UNIVERSITY OF Łódź}

The Jubilarian firmly believes that her hometown is Łódź, her home university is the University of Łódź, and her home research unit is the Chair of Etnography at the Łódź University.

Professor Wieruszeska-Adamczyk was related to the University of Łódź twice. First, in the period between 1960-1971 she was studying and working on her PhD in the Chair of Ethnography, then, between 1998-2013, as a professor in the Chair of Ethnology (the Institute of Ethnology and Cultural Anthropology). 
Professor Wieruszewska-Adamczyk's interdisciplinary approach to rural problems was crystallized and strengthened initially in the Chair of Ethnography at the UŁ and then, in the PAS Institute of Rural Development and Agriculture. The area of her interest was the methodology being a creative combination of ethnological and sociological perspectives as well as a joint approach to cultural issues (traditionally connected with ethnography) and social issues (commonly related to sociology)

Translated by Katarzyna Walińska

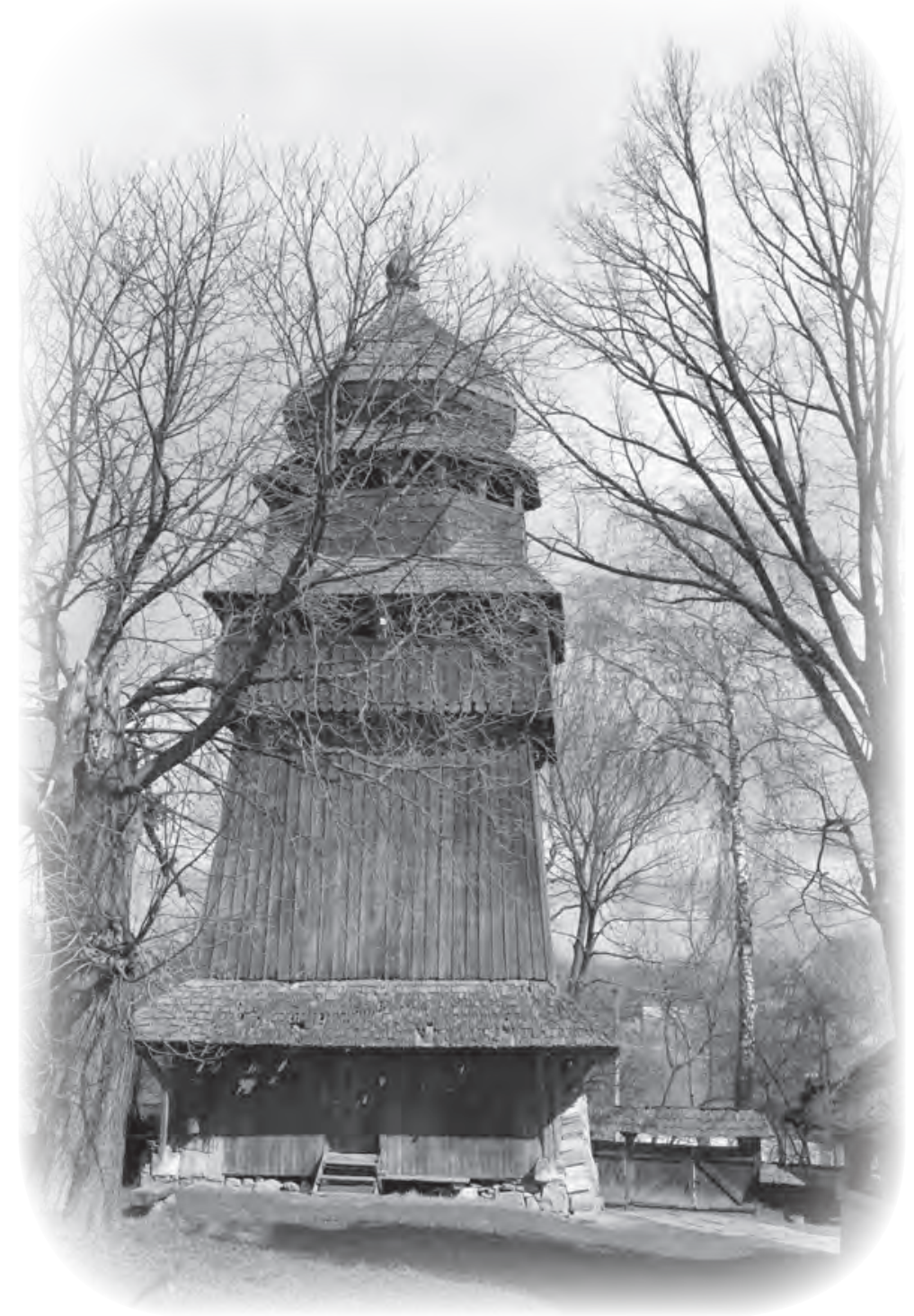

